DOI: $10.31249 / \mathrm{rsm} / 2019.01 .07$

\title{
Ф.О. Трунов
}

\section{АИПАОМАТИЯ ФРГ НА СОВРЕМЕННОМ ЭТАПЕ: РОССИЙСКОЕ НАПРАВАЕНИЕ}

Аннотация. В статье рассматривается изменение схемы применения Германией политических рычагов в отношениях с РФ с 2014 г. Участвуя в попытках Запада осуществить частичную дипломатическую изоляиию России, ФРГ старается в то же время сохранить возможности прямого доведения до нее своей позиции. Для этого используются, особенно на высшем уровне, канал телефонных переговоров, «Нормандский формат» и встречи на полях крупных международных конференций. Особое внимание уделено восстановлению межгосударственных консультаций на высшем уровне (с 2017 г.), организуемых в Сочи.

Ключевые слова: Германия; Россия; дипломатия; инструменты; «Нормандский формат».

Трунов Филипп Олегович - кандидат политических наук,

старший научный сотрудник Отдела Европы

и Америки ИНИОН РАН. E-mail: 1 trunov@mail.ru

\section{Ph.O. Trunov. Diplomacy of Germany During the Modern Period: Russian Direction}

Abstract. The article explores the change in the use of political tools by Germany in its relations with Russia since 2014. Participating in the Western attempts to ensure diplomatic isolation of Russia, Germany at the same time strives to use the elements of «soft power» in its direct relations with Moscow, such as telephone contacts, the "Normandy format» and meetings on the margin of major international conferences. Special attention is paid to the factor of the restoration of interstate consultations at the highest level (since 2017), which are organized in Sochi.

Keywords: Germany; Russia; diplomacy; tools; «Normandy format».

Trunov Philipp Olegovich - Candidate of Political Science,

Senior Researcher, Department of Europe and America,

INION RAS, Moscow. E-mail: 1 trunov@mail.ru 
Вопросам развития дипломатических отношений РФ и ФРГ посвящено много отечественных $[2 ; 3]$ и зарубежных $[8 ; 9]$ исследований. Их отличают две важные особенности. Первая - недостаток публикаций по эволюции взаимоотношений двух держав в условиях стратегического ухудшения отношений России и Запада в целом, т.е. с 2014 г. Это обусловлено незавершенностью и большой изменчивостью содержания политических диалогов обеих стран. Вторая особенность состоит в том, что в большинстве исследований внимание в основном уделялось самому контенту и результатам развития переговорного процесса. При этом недостаточно исследовалась схема использования каждой из сторон набора дипломатических инструментов и механизмов (двусторонних и многосторонних, в том числе институциализированных). Поэтому важно выявить модели применения ФРГ ее политических рычагов. Это, думается, поможет прогнозировать внешнеполитический курс державы, исторически игравшей огромную роль в налаживании диалога России с Западом. Попытаемся показать эволюцию подхода Германии к использованию дипломатических инструментов в отношении РФ с 2014 г.

В своем развитии с начала 1990-х годов отношения объединившейся Германии и постсоветской России, с одной стороны, опирались на колоссальный исторический багаж. С другой стороны, по своему характеру они существенно отличались от той модели взаимодействия между СССР и ФРГ, которая существовала в годы «классической» холодной войны. На современном этапе это обусловлено соразмерностью суммарного ресурсного потенциала двух держав (в отличие Советского Союза как сверхдержавы и «Боннской республики» как «малой державы»). Не менее важны и масштабные метаморфозы миропорядка, начавшиеся после окончания холодной войны.

В целом динамика отношений России и Германии носила скачкообразный характер: периоды подъема (1991-1994 гг. и 2001-2005 гг.) сменялись периодами ухудшения отношений.

До середины 2010-х годов временем наибольшего спада в диалоге держав считался период 1998-1999 гг. Ключевой причиной являлись глубокие разногласия сторон в подходе к урегулированию «косовской проблемы». Правительство Г. Коля / К. Кинкеля (блок ХДС / ХСС и СвДП), а вслед за ним и вновь избранное правительство Г. Шрёдера / Й. Фишера (СДПГ и Союз 90 / «Зелёные») последовательно выступали в поддержку силового давления на Югославию, перечеркивая тем самым миротворческие усилия России. В ходе последовавшего сближения стороны приступили к повышению степени институциализации сотрудничества: в 2001 г. был создан форум гражданских обществ «Петербургский диалог», параллельно кабинет Г. Шрёдера / Й. Фишера сыграл значительную роль в создании Совета Россия - НАТО (2002). Пиком сотрудничества стала координация позиций сторон в рамках «тройки» (создана в 1998 г.) РФ - ФРГ - Франция по урегулированию военно- 
политического кризиса вокруг Ирака (февраль-март 2003 г.), т.е. недопущению военной операции США и их партнеров по «коалиции желающих». С точки зрения автора, столь динамичный переход политического диалога от состояния упадка к резкому подъему обусловливался двумя факторами. Вопервых, это укрепление позиций ФРГ как нового центра влияния в евроатлантической региональной подсистеме, совпавшее с фактическим переходом США из состояния лидера (т.е. добровольно признаваемого ключевого актора) в ней к роли гегемона (доминирующего игрока, навязывающего свои решения силой). В этой ситуации высок был стратегический интерес Германии к РФ как влиятельному партнеру, расположенному за пределами ЕвроАтлантического сообщества, диалог с которым существенно укреплял позиции ФРГ как на региональном, так и глобальном уровнях. Во-вторых, интересы двух держав не пересекались на постсоветском пространстве - направлении, приобретавшем в начале XXI в. исключительное значение для РФ. Ситуация стала изменяться с середины 2000-х годов, когда в условиях расширения ЕС и НАТО на страны Восточной Европы эти структуры (а значит, и ФРГ как их весьма влиятельный участник) стали непосредственно соприкасаться с постсоветским пространством.

Этот фактор проявился уже в 2008 г. С одной стороны, Франция и Германия сыграли значимую роль в прекращении собственно боевых действий, прямо и косвенно участвуя в принятии «плана Медведева - Саркози». С другой стороны, как и ее западные партнеры, ФРГ взяла последовательный курс на поддержку официального Тбилиси, осудив признание Россией независимости Абхазии и Осетии (2008).

С начала 2010-х годов стала нарастать скорость параллельных процессов укрепления позиций ФРГ и РФ как на постсоветском пространстве, так и на Ближнем Востоке. Германия позиционировала себя как «ядро» евроатлантической региональной подсистемы, а Россия - вновь возникавшей евразийской, которая де-факто рассматривалась Западом в качестве стратегического конкурента [см.: 16]. Это определило роль региональных «болевых узлов» (особенно на пространстве СНГ) как ключевых «спойлеров» отношений двух держав. В связи с этим украинские события оказали неизмеримо большее - как по масштабу, так и по продолжительности - негативное влияние на диалог РФ и ФРГ, чем «августовская война» 2008 г.

\section{Схема применения Аипмоматических инструментов ФРГ в условиях стратегического ухудшения отношений Запада и России}

Отказ Президента Украины В.Ф. Януковича от подписания соглашения об ассоциации с ЕС в ходе Вильнюсского саммита «Восточного партнерства» 
28-29 ноября 2013 г. стал масштабным поражением дипломатии ЕС и его стран-участниц - особенно ФРГ как лидера. На фоне нараставших внутренних кризисных проявлений (финансовых и в целом экономических, институциональных и даже идеологических) успешный процесс расширения Европейского союза - как непосредственного, так и косвенного (на государства, подписавшие соглашения об ассоциации) - выступал для объединения фактором компенсации. В этой ситуации истеблишмент ФРГ и стран - участниц ЕС в целом попытался «отыграть» ситуацию назад, обеспечив сближение Украины и Европейского союза. В условиях активной поддержки Западом (особенно США) выступлений оппозиции в Киеве гарантами соглашения между ней и президентом Украины 22 февраля 2014 г. стали Германия, Франция и Польша. Однако уже 23 февраля 2014 г. оно было нарушено - к власти в Украине пришла прозападная оппозиция.

На фоне этого власти ФРГ весьма скептически воспринимали поддержку со стороны РФ регионов Украины с преобладающим русскоязычным населением. Перспективное ви́дение отношений с Россией было изложено в речи А. Меркель перед Бундестагом 13 марта 2014 г. Канцлер представила два возможных сценария:

1. В случае отказа РФ от активной поддержки русскоязычного населения (особенно на востоке Украины и в Крыму) сохранение имеющегося масштаба политико-дипломатического и экономического взаимодействия Запада с Россией. При этом для снятия опасений Кремля Германия предлагала создать Контактную группу (с участием ФРГ и ЕС, России, Украины), которую предполагалось наделить, по сути, полномочиями лишь по мониторингу ситуации.

2. При сохранении избранной Россией линии взаимодействие с ней на базе действующих переговорных форматов должно было быть свернуто. После этого должны были поэтапно вводиться санкции (в первую очередь экономические) в зависимости от масштаба шагов РФ и длительности реализации курса по поддержке русскоязычного населения в Украине. Планировалось при этом создать одну площадку (ad hoc) как механизм изменения политики России [16, S. 1520 A-1521 D].

В условиях возвращения Крыма в состав России (17 марта 2014 г.) и самопровозглашения Донецкой и Луганской народных республик, что сопровождалось началом вооруженного конфликта с ними со стороны официального Киева, германская сторона стала реализовывать второй сценарий.

С 1 апреля 2014 г. было заморожено взаимодействие с РФ по линии Альянса, в том числе прекращена деятельность Совета Россия - НАТО, который задумывался в 2000-е годы как «всепогодный формат». Германия, особенно с 2015 г., принимала активное участие в военно-тренировочной деятельности блока в Восточной Европе, масштаб которой существенно возрос. С конца 2016 г. под эгидой Альянса Германия (впервые со времен Второй мировой 
войны) развернула наземные подразделения бундесвера в регионе (в основном в Прибалтике) [1].

Однако если придание НАТО функций механизма военно-политического противодействия РФ стало уже традиционным для кризисов отношений Запада и России в XXI в., то превращение площадки ЕС в мощный инструмент экономического давления на РФ стало качественно новым явлением. Наиболее масштабные санкции были введены после уничтожения в воздухе над зоной вооруженного конфликта пассажирского «Боинга» (летел из Малайзии в Нидерланды с почти 300 пассажирами на борту) 17 июля 2014 г., в чем страны Запада обвинили Россию [17]. Так и не была реализована «Мезебергская инициатива» (2010) А. Меркель и тогдашнего Президента РФ Д.А. Медведева по созданию специального Комитета ЕС - Россия для урегулирования «проблемных узлов», особенно на постсоветском пространстве. Параллельно державы Евро-Атлантического сообщества выступили против приглашения Кремля на саммиты G8, что означало возвращение формата Большой семерки из числа исключительно западных держав (в том числе Японии).

Параллельно процесс свертывания институциализированного сотрудничества с РФ затронул и двусторонние площадки: в 2014 г. не состоялись ни межгосударственные консультации на высшем уровне, ни «Петербургский диалог». По мнению германской стороны, востребованность в запуске «тройки» РФ - ФРГ - Франция отсутствовала [см.: 16]. Кроме того, была существенно снижена интенсивность встреч в рамках дипломатии «второго трека», т.е. экспертных встреч.

Таким образом, де-юре Германия поддержала своих западных партнеров во главе с США, стремившихся ввести частичную дипломатическую изоляцию России с целью добиться кардинального пересмотра ее позиции по «украинскому вопросу» и превращения в лояльного Евро-Атлантическому сообществу партнера. Однако в процессе реализации экономических и особенно военных мер против РФ ФРГ проявляла взвешенность, стремясь осуществлять их поэтапно и не переходить «красные линии», которые могли бы спровоцировать неконтролируемую эскалацию напряженности.

Этим было чревато и возникновение полного «вакуума» на переговорном поле с РФ, чего, как бы парадоксально это ни казалось на первый взгляд, германская сторона стремилась избежать. С одной стороны, Германия прекратила свое взаимодействие с Россией по абсолютному большинству институциализированных каналов. С другой стороны, это частично компенсировалось тремя мерами германской стороны:

1) резким повышением интенсивности использования традиционных каналов - в первую очередь телефонных консультаций - для диалога на высшем уровне (см. таблицу). Этот вид переговоров позволял избежать организации полноценных двусторонних встреч, что было бы воспринято как попытка 102 
сближения с Россией до достижения целей по Украине. Одновременно этот канал позволял оперативно доводить свою позицию до оппонента;

2) запуском одного отдельного формата ad hoc, продолжение функционирования которого ставилось бы в зависимость от готовности России идти на уступки Западу (таковым с июня 2014 г. стала «Нормандская четверка»);

3) организацией кратких встреч лидеров ФРГ и РФ «на полях» форумов, где были одновременно представлены не только страны Запада, но и державы, расположенные за пределами Евро-Атлантического сообщества (в первую очередь, G20). Этот вид переговоров по своей формальной политической значимости также располагался ниже отдельных официальных встреч.

Де-юре осуществление этих мер позволяло Германии пройти между Сциллой демонтажа системы частичной дипломатической изоляции РФ и Харибдой полной потери контактов и доверия между сторонами. Между тем реализация этой линии приводила к еще одному парадоксу - основные контакты происходили на двусторонней (а не многосторонней) основе, к чему российская сторона последовательно стремилась с начала 1990-х годов. Безусловно, это не означало отказа ФРГ от роли страны - участницы ЕвроАтлантического сообщества - Германия последовательно отстаивала интересы ЕС и НАТО, но сквозь призму своих интересов в этих организациях. Такая позиция позволяла сохранять диалог, не допуская неконтролируемой эскалации военно-политической напряженности.

Резкий рост интенсивности телефонных переговоров между лидерами ФРГ и РФ наблюдался с 20 февраля по конец марта 2014 г. (восемь контактов), что было связано со стремлением А. Меркель довести до своего визави сущность и возможный масштаб рестриктивных мер в отношении России. На решение этой задачи были направлены и усилия главы МИД ФРГ Ф.-В. Штайнмайера, проведшего рабочую встречу с С.В. Лавровым и В.В. Путиным еще 14 февраля 2014 г., незадолго до попытки легализации бывшей оппозиции в руководстве Украины [5]. Но в апреле - середине мая 2014 г. на фоне возникновения очага боевых действий на востоке Украины телефонное общение на высшем уровне было сведено к минимуму (лишь один контакт), а параллельно была введена первая волна экономических санкций.

Напротив, с конца мая 2014 г. наблюдалась новая волна интенсификации телефонных контактов - только в июне-июле их было по пять ежемесячно. 24 мая 2014 г. впервые консультации были проведены с участием президента Ф. Олланда [10]. Именно на них германо-французский тандем инициировал запуск четырехстороннего (с участием РФ и Украины) формата, первая встреча которого была организована на праздновании 70-летия высадки западных союзников в Нормандии (откуда и произошло его название). Телефонные переговоры 24 мая 2014 г. показали заинтересованность ФРГ 
в возобновлении консультаций в формате «тройки». Однако если в 2003 г. внутренняя схема взаимодействия трех держав описывалась формулой «1+1+1», то теперь - «2+1», т.е. германо-французский тандем стремился оказать консолидированное влияние на РФ с целью отказа от поддержки ею ДНР и ЛНР. Де-юре стороны сходились в необходимости скорейшего полного прекращения огня. Однако механизмы достижения этой цели (вновь созданная Контактная группа с участием Украины, ДНР и ЛНР, ОБСЕ, а также мониторинговая миссия ОБСЕ) оказались недостаточными, а германофранцузский тандем не оказывал необходимого по масштабу влияния на власти в Киеве для прекращения ими боевых действий.

Как видно из таблицы, лишь небольшая часть телефонных переговоров проводилась ФРГ с РФ в формате «четверки»: большинство из них проходили в двустороннем или трехстороннем формате. В июле-августе 2014 г. сформировалась следующая схема консультаций: сначала германо-французский тандем согласовывал свои позиции с вновь избранным президентом П. Порошенко и лишь затем с руководством РФ. Учет позиции официального Киева был для держав ЕС актуален вдвойне в условиях неоднократных попыток наступления украинских войск, сумевших серьезно сократить площадь подконтрольной ДНР и ЛНР территории. В этой связи власти Украины призывали своих западных партнеров де-факто говорить с позиций силы после полной ликвидации самопровозглашенных республик [15].

Интенсивность телефонных консультаций вновь резко сократилась в конце августа - начале сентября 2014 г., когда войска ДНР и ЛНР перешли в контрнаступление. Оно стало предпосылкой заключения договоренностей «Минск-1» (5 сентября 2014 г.) о прекращении огня между официальным Киевом и самопровозглашенными республиками при посреднической роли РФ. Германия и Франция не участвовали в ведении переговоров - более того, в день подписания «Минска-1» обе страны поддержали решение Уэльсского саммита НАТО о серьезном наращивании общих для стран - участниц Альянса военных механизмов (в первую очередь, сил быстрого реагирования). Чем это обусловлено? Заключение договоренностей о прекращении огня являлось промежуточной, но не итоговой целью держав ЕС, ибо не означало кардинального пересмотра политики России в «украинском вопросе». Кроме того, «Минск-1» рассматривался на Западе как соглашение с участием сторон вооруженного конфликта, т.е. и России, хотя она последовательно отрицала это, рассматривая себя лишь как посредника.

Вместе с тем германская дипломатия стремилась добиться выполнения «Минска-1» от сторон - в первую очередь от самопровозглашенных республик (через Россию). Этим обусловлен рост телефонных консультаций в конце сентября - октябре (три контакта) и конце декабря (два контакта), когда 
вновь появились признаки «размораживания» вооруженного конфликта по всей линии соприкосновения сторон.

СТАТИСТИКА ТЕАЕФОННЫХ ПЕРЕГОВОРОВ КАНЦАЕРА ФРГ

Таблица * И ПРЕЗИАЕНТА РОССИИ (2013 - МаЙ 2018 г.)

\begin{tabular}{|l|c|c|c|c|c|c|c|}
\hline Год & 2013 & 2014 & 2015 & 2016 & 2017 & $2018^{* *}$ & Bсего \\
\hline $\begin{array}{l}\text { Общее число телефонных пере- } \\
\text { говоров }\end{array}$ & 2 & 29 & 13 & 3 & 7 & 5 & 69 \\
\hline $\begin{array}{l}\text { в том числе в «Нормандском } \\
\text { формате» }\end{array}$ & 0 & $\begin{array}{c}4 \\
(14 \%)\end{array}$ & $\begin{array}{c}6 \\
(46 \%)\end{array}$ & 0 & $\begin{array}{c}2 \\
(29 \%)\end{array}$ & 0 & $\begin{array}{c}12 \\
(17 \%)\end{array}$ \\
\hline $\begin{array}{l}\text { в том числе в трехстороннем } \\
\text { формате (РФ - ФРГ - Фран- } \\
\text { ция) }\end{array}$ & 0 & $\begin{array}{c}4 \\
(14 \%)\end{array}$ & $\begin{array}{c}3 \\
(23 \%)\end{array}$ & $\begin{array}{c}2 \\
(67 \%)\end{array}$ & $\begin{array}{c}2 \\
(29 \%)\end{array}$ & $\begin{array}{c}1 \\
(20 \%)\end{array}$ & $\begin{array}{c}12 \\
(17 \%)\end{array}$ \\
\hline
\end{tabular}

* Рассчитано автором на основе сайта Ведомства федерального канцлера (https://www. bundesregierung.de/SiteGlobals/Forms/Webs/Breg/Suche/DE).

${ }^{* *}$ По состоянию на 25 мая 2018 г.

Во время первого витка вооруженного конфликта на востоке Украины (с апреля по начало сентября 2014 г.) существовала явная диспропорция объемов и, главное, характера взаимодействия германо-французского тандема в пользу официального Киева по сравнению с Кремлем. В условиях новой вспышки организованного насилия (с конца января по середину февраля 2015 г.) ФРГ и Франция де-факто стали стремиться к более сбалансированной позиции. Во-первых, был понижен градус критики РФ в вопросе невыполнения с западной точки зрения договоренностей «Минск-1». Во-вторых, в условиях возобновления работы «Нормандского формата» как на высоком, так и на высшем уровнях германо-французский тандем стал выполнять функции «челночной дипломатии», стремясь найти взаимоприемлемое решение на основе «Минска-1». Предварительным этапом стало резкое повышение интенсивности телефонных контактов в январе (четыре), а основным - специальный визит А. Меркель и Ф. Олланда в Москву 7 февраля и последовавшая выработка и подписание соглашения «Минск-2» 12 февраля 2015 г. Документ состоял из трех основных блоков:

- миротворческого; согласно ему, устанавливались жесткие сроки мер по обеспечению режима прекращения огня (в частности, отвод тяжелых вооружений - в течение двух недель);

- общеполитического; в основе лежало компромиссное решение о сохранении территорий ДНР и ЛНР в составе Украины в обмен на предоставление им особого статуса после проведения местных выборов;

- экономического; он закреплял общую необходимость восстановления жилья, коммунального хозяйства и производственных мощностей в зоне конфликта [4]. 


\section{РОССИЯ И МИР В ХХІ ВЕКЕ}

Этот документ стал, по сути, первой «стратегической сделкой» между РФ и германо-французским тандемом со времени начала украинских событий. «Минск-2» имел двоякие последствия: с одной стороны, он стал точкой отсчета для восстановления взаимного доверия (оказавшегося крайне медленным), с другой - одновременно и препятствием в случае своего невыполнения.

В первую неделю после подписания «Минска-2» интенсивность телефонных консультаций на высшем уровне была сверхвысокой (пять контактов). Это было связано с тем, что начать реализацию документа было сложно из-за ликвидации формированиями ЛНР и ДНР «дебальцевского котла» ${ }^{1}$. В дальнейшем общее количество телефонных переговоров стало падать, но при этом росло их число в формате «Нормандской четверки». Ключевой причиной тому стало «пробуксовывание» «Минска-2» по всем блокам. Официально западные страны возлагали основную долю ответственности на Россию и обе поддерживаемые ею народные республики. Именно это стало главным посылом А. Меркель во время ее рабочего визита в Москву 10 мая 2015 г. в связи с 70-летием Победы [7].

Вместе с тем переговоры между ФРГ и РФ привели и к положительным результатам. Первый - сохранение приверженности «Минску-2», несмотря на срыв сроков, что указывало на взаимное стремление к потеплению отношений. Второй результат: несмотря на частые отдельные вспышки боевых действий, в целом «размораживания» вооруженного конфликта не произошло. Большое значение имело усиление попыток германо-французского тандема подвигнуть власти в Киеве к реализации «Минска-2». Это влияло и на готовность ФРГ к поиску путей постепенного улучшения отношений с РФ. Примечательно, что в октябре 2015 г. вновь (после перерыва в 2014 г.) был проведен форум «Петербургский диалог», проходивший в Потсдаме.

30 ноября 2015 г. по инициативе А. Меркель на полях конференции ООН по борьбе с изменениями климата была проведена встреча с В.В. Путиным. Стороны затронули не только «украинский вопрос»- причем с точки зрения нормализации экономических отношений между ЕС, Украиной и Россией (с участием П. Порошенко), но и борьбу с «Исламским государством» ${ }^{2}$ [12]. Сам формат этой встречи (с участием Украины и на полях международной конференции) показывал, что формально ФРГ еще не готова к всеобъемлю-

\footnotetext{
1. Самой восточной точкой наступления ВСУ и формально лояльных официальному Киеву военизированных формирований являлось Дебальцево. Войскам ДНР и ЛНР удалось окружить здесь одну из ударных группировок, что стало предпосылкой готовности властей Украины подписать «Минск-2». - Прим. авт.

2. Запрещенная в России террористическая организация. - Прим. авт. 
щему восстановлению политико-дипломатических каналов взаимодействия с РФ, но ищет пути интенсификации диалога.

В первую очередь это обусловливалось глубоким изменением внешнеполитической обстановки вокруг Германии. ФРГ и ее партнеры по ЕС в условиях разрастания вооруженного конфликта в Сирии оказались подвержены двум тесно связанным угрозам: массовой иммиграции и росту террористической угрозы (со стороны ИГ). Отказываясь от активного военно-политического сотрудничества с Ираном и правительством Б. Асада в пользу «умеренной» оппозиции (и курдов), державы Запада не могли эффективно противодействовать стремительному росту мощи ИГ. Не решило эту задачу и создание второй западной антитеррористической коалиции (с сентября 2014 г.). Напротив, с началом совместной с САР и ИРИ операции Вооруженных сил РФ в Сирии (с 30 сентября 2015 г.) наблюдались постепенная потеря ИГ инициативы и отход его войск. На этом фоне ход встречи 30 ноября 2015 г. показал понимание официальным Берлином безальтернативности решения «сирийского вопроса» с участием России.

С 2016 г. глубокие сдвиги стали наблюдаться и внутри евро-атлантической региональной подсистемы. Начало выхода Великобритании из ЕС (май 2016 г.) и избрание внесистемного с точки зрения западного истеблишмента кандидата Д. Трампа президентом США (ноябрь 2016 г.) стали «стратегическими шоками» для Германии. В то же время эти факторы расширили возможности по ускоренному утверждению ФРГ в качестве одного из центров притяжения в евро-атлантической региональной подсистеме. Необходимость реагировать на несогласованные с партнерами и часто разрушительные действия администрации Д. Трампа (в частности, по выходу из «ядерной сделки» с Ираном), стремление укрепить собственное влияние в мире побуждали Германию активизировать политико-дипломатическое взаимодействие с Россией - особенно двусторонних встреч лидеров. Однако, представляя себя как защитницу демократических принципов и коллегиальных решений ЕвроАтлантического сообщества, Германия была не готова и, главное, не могла с учетом позиции партнеров пойти на «размораживание» многосторонних диалоговых площадок с Россией ${ }^{3}$.

Такое положение дел предполагало, во-первых, продолжение встреч на полях многосторонних форумов - в частности, G20 в Гамбурге 7-8 июля 2017 г., где А. Меркель обсудила с В.В. Путиным широкий спектр вопросов, выходящих за рамки решения «украинского вопроса». Во-вторых, восстанав-

3. Так, при поддержке ФРГ с 2016 г. вновь стали происходить единичные консультаиии Совета Россия - НАТО. Однако из-за сопротивления ряда государств Альянса (в частности, стран Балтии и Польши), работа этого формата полностью не была перезапущена. - Прим. авт. 


\section{РОССИЯ И МИР В ХХІ ВЕКЕ}

ливался механизм двусторонних межгосударственных консультаций на высшем уровне.

\section{Авусторонние переговоры на высшем уровне: На пути к восстановмению стратегического партнерства?}

На фоне стратегического ухудшения отношений Запада и России резко сократилась интенсивность переговоров на высшем уровне в двустороннем формате. Так, за весь третий срок президентства В.В. Путин лишь однажды прибыл в Германию с рабочим визитом (2012) и ни разу - с государственным. В свою очередь, с германской стороны двухлетняя пауза наступила после поездки А. Меркель в РФ в связи с 70-летием Победы. Примечательно, что она состоялась лишь 10 мая 2015 г., т.е. после традиционного парада, на фоне украинских событий воспринимавшегося на Западе как одна из нарочитых демонстраций военно-политической мощи РФ.

Лишь 2 мая 2017 г. вновь состоялся рабочий визит канцлера Германии в Россию. Формально переговоры, проходившие в резиденции президента РФ Бочаров ручей (г. Сочи), рассматривались сторонами как подготовка к саммиту G20 в Гамбурге (7-8 июля 2017 г.). В реальности это была первая, весьма осторожная, попытка взаимного зондажа позиций на предмет их сближения. Об этом свидетельствовало акцентирование внимания на экономическом сотрудничестве - даже в условиях введения санкций ЕС это направление было менее проблемным, чем общеполитическое [13]. Связывая их, канцлер А. Меркель обратила внимание на возможность отмены санкций в случае выполнения «Минска-2» [там же]. Однако на встрече не было выдвинуто инициатив по «дореализации» этих договоренностей. По «сирийской проблеме» стороны согласились с необходимостью увязывать воедино переговорные процессы в Женеве и Астане. Это свидетельствовало о признании растущей роли России в урегулировании вооруженного конфликта в САР.

В фокусе внимания сторон также оказалась борьба с международным терроризмом - трек, содержавший значительный потенциал для взаимодействия. С одной стороны, ФРГ как страна - участница западной антитеррористической коалиции, де-факто конкурирующей с объединением РФ - САР ИРИ для борьбы с «Исламским государством», не выдвинула инициатив по налаживанию координации между ними. С другой стороны, А. Меркель воздержалась от критики как сирийских властей во главе с Б. Асадом, так и российской военной помощи [13]. Это разительно контрастировало с попытками Германии возложить на РФ, САР и Иран ответственность за начало боев в Алеппо в октябре-ноябре 2016 г. [6]. При этом внимание стороны сосредоточили на возникавшей гуманитарной катастрофе. На практике же не менее 
важной задачей являлось спасение остатков «умеренной» оппозиции от полного разгрома.

За год, прошедший со времени встречи 2 мая 2017 г., наметилось постепенное сближение позиций двух держав по многим «болевым узлам». Так, снизилась критика РФ со стороны ФРГ как по «сирийской проблеме», так и по «украинскому вопросу». Более того, Германия позитивно восприняла инициативу Кремля о развертывании на востоке Украины миротворческих сил $\mathrm{OOH} \mathrm{в} \mathrm{зоне} \mathrm{деятельности} \mathrm{мониторинговой} \mathrm{миссии} \mathrm{ОБСЕ} \mathrm{с} \mathrm{целью} \mathrm{«замора-}$ живания» вооруженного конфликта как основы для дальнейшей реализации «Минска-2». Официальный Берлин проявил готовность к сохранению стратегических сделок с участием РФ: в большей степени это положение относилось к многосторонним договоренностям (соглашение по военной денуклеаризации Ирана (2015)), в меньшей - к двусторонним («Северный поток-2»). Причем проведение этой линии сталкивалось с серьезными как внешними (в первую очередь, давление администрации Д. Трампа), так и внутренними препятствиями. К их числу относился кризис с формированием правительства, затянувшийся на полгода, что произошло впервые в новейшей (с 1949 г.) политической истории ФРГ. Провал переговоров о создании правительства в составе блока ХДС / ХСС, «Зелёных» и СвДП (ноябрь 2017 г.) и трудностей формирования кабинета «большой коалиции» (христианских демократов и социал-демократов) (возник в марте 2018 г.) снизили уровень легитимности IV кабинета A. Меркель. В связи с этим примечательно, что власти ФРГ не поставили под сомнение итоги выборов президента России (около 77\% голосовавших поддержали В.В. Путина), поздравив его сразу после переизбрания 18 марта 2018 г.

На этом фоне 18 мая 2018 г. состоялся очередной рабочий визит А. Меркель в Россию - переговоры вновь проходили в резиденции Бочаров ручей. На этот раз они отличались потеплением отношений и бо́льшей конкретностью при обсуждении вопросов взаимодействия. А. Меркель и В.В. Путин отмечали растущую экономическую взаимозависимость сторон: в РФ было 5 тыс. германских предприятий (270 тыс. занятых), в ФРГ 1,5 тыс. российских. Была достигнута предварительная стратегическая договоренность по «Северному потоку-2»: подтверждение его строительства в обмен на сохранение поставок газа через Украину ${ }^{4}$, при условии, как подчеркнул В.В. Путин, их экономической целесообразности [14]. Примечательно,

4. Тезис сохранения Украины без средств, получаемых за транзит газа РФ через свою территорию, был ключевым в аргументации украинского истеблишмента, пытавшегося «торпедировать» реализацию «Северного потока-2». В частности, он был высказан президентом П. Порошенко в ходе встречи лидеров ФРГ и Франции в апреле 2018 г. в Аахене. - Прим. авт. 
что в ходе пресс-конференции сторонами не был затронут вопрос о санкциях. Это, по мнению автора, означало, что проблема, учитывая сложность ее разрешения в ближайшей перспективе, была временно выведена за скобки для ускорения общего процесса сближения.

На фоне отказа администрации Д. Трампа от подписания договора о Трансатлантическом партнерстве и готовности начать «таможенную войну» против ЕС развитие экономических отношений с РФ (и в целом с крупными государствами за пределами Евро-Атлантического сообщества) приобретало для ФРГ особое значение. Рост внешней торговли, как отмечали западные исследователи, был одним из ключевых инструментов утверждения Германии в качестве глобальной державы [11, p. 5-10].

На пресс-конференции по итогам первого (один на один) раунда переговоров В.В. Путин следующим образом обозначил последовательность политико-военных тем для обсуждения: сохранение иранской «ядерной сделки», урегулирование «сирийской проблемы» и вооруженного конфликта на востоке Украины. А. Меркель представила обратный порядок рассмотрения этих вопросов, т.е. начинала с направления, где имелись наибольшие расхождения [14]. С учетом проведения переговоров на высшем уровне в РФ (причем во второй раз подряд) эта последовательность указывает, что де-факто Россия выступала инициатором сближения, причем степень заинтересованности руководства ФРГ в выработке приемлемых стратегических решений была даже выше.

Автор полагает, что в данном случае А. Меркель вернулась к принципам «прецедентной дипломатии» времен канцлера Г. Коля: действовать в авангарде партнеров, определяя стратегическую повестку дня. Так, продолжением этой встречи можно считать переговоры Президента Франции Э. Макрона с В.В. Путиным на ПМЭФ 24 мая 2018 г.

По Украине на встрече 18 мая 2018 г. стороны признали необходимость развертывания миротворческой миссии ООН в зоне конфликта, а также возобновления работы «Нормандского формата» Это означало снижение интереса ФРГ к трехсторонним встречам (с участием германо-французского тандема и Украины). Стороны расставили акценты в вопросах экономического восстановления Сирии и координации переговоров в Женеве и Астане. Договорились они и о координации позиций и по краеугольному вопросу - подготовке конституционной реформы в САР [там же], т.е. определении перспективной политической архитектуры страны.

ФРГ и РФ подтвердили приверженность выполнению обязательств по иранской «ядерной сделке», несмотря на объявленный 8 мая 2018 г. администрацией Д. Трампа выход из нее. Наряду со стремлением «развязать» «сирийской узел» эти шаги демонстрировали совместный интерес двух держав к стабилизации обстановки на Ближнем и Среднем Востоке. 
Таким образом, в целом канцлеру ФРГ и президенту РФ удалось прочертить магистральные линии взаимодействия по ключевым политико-военным и экономическим вопросам. При этом германская сторона пошла на серьезные уступки и, что не менее важно, продемонстрировала готовность к будущему, хотя и очень медленному, восстановлению уровня отношений до 2014 г. Чем это обусловлено?

Во-первых, ослаблением атлантических связей в условиях ужесточения подхода США к диалогу с европейскими партнерами. Это, как уже отмечалось, создает «окно возможностей» для укрепления позиций ФРГ в евроатлантической региональной подсистеме. Для этого официальному Берлину нужно усиливать позиции и на глобальном уровне, в том числе налаживая отношения с Россией. Но подчеркнем еще раз: нельзя преувеличивать значения этих шагов - ФРГ последовательно продолжает рассматривать себя как государство - член Евро-Атлантического сообщества и не готова пойти на пересмотр противоречащих этому положений своей внешней политики для сближения со странами, находящимися за его пределами.

Во-вторых, Германия все более «увязает» в решении «сирийской проблемы» и «украинского вопроса». Они не только оттягивают значительные (особенно политические и экономические) ресурсы ФРГ, но и мешают ее стратегическому закреплению на постсоветском пространстве и на Ближнем Востоке и продвижению в более отдаленные регионы. В связи с увеличением ресурсных возможностей (особенно политико-военных) и ростом влияния России в мире в Берлине все отчетливее осознают, что без РФ невозможно достичь реального урегулирования вооруженных конфликтов ни в Сирии, ни на востоке Украины.

Сам факт майских встреч на высшем уровне на территории РФ является успехом российской дипломатии. Кремлю удалось найти путь ведения переговоров с Германией в двустороннем, а не многостороннем формате. Весьма высока вероятность возникновения ежегодного «сочинского формата» диалога на высшем уровне РФ и ФРГ. Окончательно это прояснится уже в краткосрочной перспективе, что может существенно изменить схему использования Германией своих дипломатических инструментов на российском направлении.

В 2014 г. ФРГ приняла активное участие в усилиях коллективного Запада по частичной дипломатической изоляции РФ посредством демонтажа большинства имевшихся переговорных двусторонних и многосторонних площадок. Параллельно германская сторона стала искать обходные каналы донесения информации до РФ, формально не являвшиеся столь же политически значимыми как «замороженные» с 2014 г. При этом де-факто взаимодействие 
стало в основном развиваться по двусторонним (или трехсторонним - с участием Франции) трекам. Это обеспечивало возможность продолжения переговорного процесса в условиях стратегического ухудшения отношений институтов Запада (ЕС, НАТО) с РФ.

В ситуации «игры вдолгую» правительство ФРГ стало проявлять интерес к наращиванию дипломатических контактов с Россией. Это было обусловлено не только вызовами извне евро-атлантической региональной подсистемы, но и впервые с начала 1990-х годов изнутри нее.

Формально германское руководство не выступает в поддержку восстановления «замороженных» переговорных площадок, особенно многосторонних. Однако на практике происходит восстановление двусторонних форматов для взаимодействия (в частности, Петербургский диалог), из которых особое значение приобретает механизм межгосударственных консультаций на высшем уровне (с 2017 г.).

Это позволяет предположить, что в перспективе именно ФРГ сможет взять на себя ключевую роль в восстановлении стратегического доверия между Россией и Западом. Так, Германия может выступить инициатором налаживания более тесного взаимодействия между Россией и «евротройкой» (Е3) (ФРГ, Франция, Великобритания) как по имплементации иранской «ядерной сделки», так и в сфере контроля над вооружениями в целом. Соответственно, процесс потепления двусторонних отношений будет опережать темпы нормализации диалога коллективного Запада и России. В ближайшей перспективе обе эти тенденции будут развиваться по принципу «малых шагов». Высокую скорость развития они могут приобрести лишь к середине 2020-х годов.

\section{Библиография}

1. Буланов К. В НАТО заявили об участии 16 стран в ротации сил в Восточной Европе // РБК. 2016. 26 окт. URL: http://www.rbc.ru/politics/26/10/2016/581105489a7947ab15d62082 (Дата обращения: 19.05.2018.)

2. Воробьева Л.М. Внешняя политика ФРГ на пороге XXI века. М.: РИСИ, 2000. 354 с.

3. Павлов Н.В. Внешняя политика ФРГ в постбиполярном мире. М.: Наука, 2005. 410 с.

4. Полный текст Минских соглашений // РИА Новости. 2015. 12 февр. URL: https://ria.ru/ world/20150212/1047311428.html (Дата обращения: 19.05.2018.)

5. Ausführliche Gespräche in Moskau. 14. Februar 2014 // Die Bundesregierung: Official Website. 2014. 14. Feb. URL: https://www.bundesregierung.de/Content/DE/Meldungen/2014/02/ 2014-02-13-steinmeier-moskau.html (Дата обращения: 19.05.2018.)

6. Außenminister Steinmeier begrüßt Entsendung von UN-Beobachtern nach Aleppo // Auswärtiges Amt: Official Website. 2016. 20. Dez. URL: http://www.auswaertigesamt.de/DE/Aussenpolitik/Laender/Aktuelle_Artikel/Syrien/201216_Syrien_UNBeobachter.html (Дата обращения: 19.05.2018.)

7. Begrüßungsstatement von Bundeskanzlerin Angela Merkel und Präsident Wladimir Putin am 10. Mai 2015 in Moskau // Die Bundesregierung: Official Website. URL: https://www.bundes- 
regierung.de/Content/DE/Mitschrift/Pressekonferenzen/2015/05/2015-05-10-statement-merkel-moskau. $\mathrm{html}$ (Дата обращения: 19.05.2018.)

8. Bos El. Deutsche Interessen und Zielen im GUS-Raum // Handbuch zur deutschen Außenpolitik / S. Schmidt, G. Hellmann, R. Wolf (Hrsg.). Wiesbaden: Verlag für Sozialwissenschaften; GWV Fachverlage GmbH, 2007. S. 456-461.

9. Von Bredow W. Die Außenpolitik der Bundesrepublik Deutschland. Eine Einführung. Wiesbaden: Verlag für Sozialwissenschaften; GWV Fachverlage GmbH, 2006. 306 S.

10. Bundeskanzlerin Merkel telefonierte gemeinsam mit Hollande und Putin // Die Bundesregierung: Official Website. 2014. 14. Mai. URL: https://www.bundesregierung.de/Content/DE/ Pressemitteilungen/BPA/2014/05/2014-05-24-telefonat-merkel-hollande-putin.html (Дата обращения: 19.05.2018.)

11. Lough J. Germany's Russia challenge. Fellowship monograph. Napoli: NATO Defense College, 2018. $47 \mathrm{p}$.

12. Merkel spricht mit Putin über Kampf gegen IS // Die Bundesregierung: Official Website. 2015. 30. Nov. URL: https://www.bundesregierung.de/Content/DE/Artikel/2015/11/2015-11-30merkel-putin-poroschenko.html (Дата обращения: 19.05.2018.)

13. Pressekonferenz von Bundeskanzlerin Merkel und dem russischen Präsidenten, 2. Mai 2017 // Die Bundesregierung: Official Website. 2017. 2. Mai. URL: https://www.bundesregierung.de/ breg-de/aktuelles/pressekonferenzen/pressekonferenz-von-bundeskanzlerin-merkel-und-dem-russischenpraesidenten-putin-844758 (Дата обращения: 19.05.2018.)

14. Pressekonferenz von Bundeskanzlerin Merkel und dem russischen Präsidenten Wladimir Putin, 18. Mai 2018 // Die Bundesregierung: Official Website. 2018. 18. Mai. URL: https://www.bundesregierung.de/Content/DE/Mitschrift/Pressekonferenzen/2018/05/2018-05-18-pkmerkel-putin-sotschi.html (Дата обращения: 19.05.2018.)

15. Pressekonferenz von Bundeskanzlerin Merkel und dem ukrainischen Präsidenten Petro Poroschenko am 23. August // Die Bundesregierung: Official Website. 2014. 23. August. URL: https:/www.bundesregierung.de/Content/DE/Mitschrift/Pressekonferenzen/2014/08/2014/2014-0823-pk-kiew.html (Дата обращения: 19.05.2018.)

16. Rede von Dr. Angela Merkel, Bundeskanzlerin. Zum Treffen der Staatsund Regierungschefs der Europäischen Union zur Lage in der Ukraine am 6. März 2014 // Deutscher Bundestag, 18. Wahlperiode. Plenarprotokoll 18/20. Berlin, Donnerstag, den 13. März 2014. S. 1518 C-1521 D.

17. Weitere Sanktionen gegen Russland // Die Bundesregierung: Official Website. 2014. 15. Juli. URL: https://www.bundesregierung.de/Content/DE/Reiseberichte/2014-07-15-er-sanktionenrussische-unternehmen.html (Дата обращения: 19.05.2018.)

\section{References}

Bulanov K. V NATO zajavili ob uchastii 16 stran v rotacii sil v Vostochnoj Evrope // RBK. 2016. Oct. 26 / URL: http://www.rbc.ru/politics/26/10/2016/581105489a7947ab15d62082 (Data obrashhenija: 19.05.2018.)

Vorob'eva L.M. Vneshnjaja politika FRG na poroge XXI veka. Moscow: RISI, 2000. 354 p.

Pavlov N.V. Vneshnjaja politika FRG v postbipoljarnom mire. Moscow: Nauka, 2005. 410 p.

Polnyj tekst Minskih soglashenij // RIA Novosti. 2015. Febr. 12. URL: https://ria.ru/ world/20150212/1047311428.html (Data obrashhenija: 19.05.2018.)

Ausführliche Gespräche in Moskau. 14. Februar. 2014 // Die Bundesregierung: Official Website. 2014. 14. Feb. URL: https://www.bundesregierung.de/Content/DE/Meldungen/2014/02/ 2014-02-13-steinmeier-moskau.html (Data obrashhenija: 19.05.2018.) 


\section{РОССИЯ И МИР В ХХІ ВЕКЕ}

Außenminister Steinmeier begrüßt Entsendung von UN-Beobachtern nach Aleppo // Auswärtiges Amt: Official Website. 2016. 20. Dez. URL: http://www.auswaertiges-amt.de/DE/Aussenpolitik/Laender/Aktuelle_Artikel/Syrien/201216_Syrien_UNBeobachter.html (Data obrashhenija: 19.05.2018.)

Begrüßungsstatement von Bundeskanzlerin Angela Merkel und Präsident Wladimir Putin am 10. Mai 2015 in Moskau // Die Bundesregierung: Official Website. URL: https://www.bundes regierung.de/Content/DE/Mitschrift/Pressekonferenzen/2015/05/2015-05-10-statement-merkel-moskau. html (Data obrashhenija: 19.05.2018.)

Bos El. Deutsche Interessen und Zielen im GUS-Raum // Handbuch zur deutschen Außenpolitik / S. Schmidt, G. Hellmann, R. Wolf (Hrsg.). Wiesbaden: Verlag für Sozialwissenschaften; GWV Fachverlage GmbH, 2007. S. 456-461.

Von Bredow W. Die Außenpolitik der Bundesrepublik Deutschland. Eine Einführung. Wiesbaden: Verlag für Sozialwissenschaften; GWV Fachverlage GmbH, 2006. 306 S.

Bundeskanzlerin Merkel telefonierte gemeinsam mit Hollande und Putin // Die Bundesregierung: Official Website. 2014. 14. Mai. URL: https://www.bundesregierung.de/Content/DE/ Pressemitteilungen/BPA/2014/05/2014-05-24-telefonat-merkel-hollande-putin.html (Data obrashhenija: 19.05.2018.)

Lough J. Germany's Russia challenge. Fellowship monograph. Napoli: NATO Defense College, 2018. $47 \mathrm{p}$.

Merkel spricht mit Putin über Kampf gegen IS // Die Bundesregierung: Official Website. 2015. 30. Nov. URL: https://www.bundesregierung.de/Content/DE/Artikel/2015/11/2015-11-30-merkelputin-poroschenko.html (Data obrashhenija: 19.05.2018.)

Pressekonferenz von Bundeskanzlerin Merkel und dem russischen Präsidenten, 2. Mai. 2017 // Die Bundesregierung: Official Website. 2017. 2. Mai. URL: https://www.bundesregierung.de/bregde/aktuelles/pressekonferenzen/pressekonferenz-von-bundeskanzlerin-merkel-und-dem-russischenpraesidenten-putin-844758 (Data obrashhenija: 19.05.2018.)

Pressekonferenz von Bundeskanzlerin Merkel und dem russischen Präsidenten Wladimir Putin, 18. Mai. 2018 // Die Bundesregierung: Official Website. 2018. 18. Mai. URL: https://www.bundesregierung.de/Content/DE/Mitschrift/Pressekonferenzen/2018/05/2018-05-18-pk-merkel-putin-sotschi. html (Data obrashhenija: 19.05.2018.)

Pressekonferenz von Bundeskanzlerin Merkel und dem ukrainischen Präsidenten Petro Poroschenko am 23. August // Die Bundesregierung: Official Website. 2014. 23. August. URL: https://www.bundesregierung.de/Content/DE/Mitschrift/Pressekonferenzen/2014/08/2014/2014-0823-pk-kiew.html (Data obrashhenija: 19.05.2018.)

Rede von Dr. Angela Merkel, Bundeskanzlerin. Zum Treffen der Staatsund Regierungschefs der Europäischen Union zur Lage in der Ukraine am 6. März. 2014 // Deutscher Bundestag, 18. Wahlperiode. Plenarprotokoll 18/20. Berlin, Donnerstag, den 13. März. 2014. S. 1518 C-1521 D.

Weitere Sanktionen gegen Russland // Die Bundesregierung: Official Website. 2014. 15. Juli. URL: https:/www.bundesregierung.de/Content/DE/Reiseberichte/2014-07-15-er-sanktionen-russischeunternehmen.html (Data obrashhenija: 19.05.2018.) 